\title{
Styl życia studentek a ich przekonania zdrowotne i preferowane wartości
}

\author{
Abstract \\ Lifestyle of female students and their health convictions \\ and preferred values
}

Introduction: Lifestyle is one of the most important factors related to the health of each individual which can be controlled and modified. Connection between health, the quality of life and productivity at work, understandable especially for the educated and young people, is not respected by them in the preventive practice. Recently media have been alarming about the increasing statistics of obesity among young people, their poor physical and mental condition as well as the increasing number of people with so-called social diseases. The decisive factor in human proceedings includes core values that not only imply a lifestyle and its quality but also influence the development and the form of a person's way of life. Therefore, there is a question what kind of lifestyle students of the University of Gdańsk lead and what the relation between their lifestyle, health beliefs and their core values is.

Purpose: The aim of the study is to clarify the connection between the lifestyle, health convictions and preferred values of female students at the University of Gdansk.

Material and methods: Dean's groups of full-time studies were selected to take part in the study including 1 st year students attending obligatory fitness classes studying at different departments during the academic year 2006/2007. The results of 150 people were analized statistically. The students were between 19-24 and the average age was 20.3. A questionnaire was used for quantitative research.

Conclusions: Only $43 \%$ of students in the examined group lead healthy lifestyle which may cause concern and may suggest a lack of knowledge in this field. The quality of meals and physical activity are the variables strongly differentiating female students in terms of their lifestyles. The results confirm earlier observations, showing that female students who lead a healthy lifestyle (PLUS group) appreciate following the desire for achieving and maintaining physical fitness as it is an expression of health that they highly appreciate as a value. 


\section{Wprowadzenie}

Zdrowie - niekwestionowana wartość, dla większości z nas największa, od lat znajduje się w kręgu zainteresowań nauki nie tylko medycznej. Podejmowane są badania nad poszukiwaniem czynników warunkujących zdrowie człowieka i wyrazem tych poszukiwań przez medycynę, zmierzających do poprawy stanu zdrowia społeczeństw, w latach osiemdziesiątych XX wieku stało się pojęcie „styl życia", przyjęte jako jeden z faktorów społecznych kształtujących zdrowie. Największy rozgłos, a także znaczenie dla miejsca, jakie styl życia zajmuje obecnie w problematyce zdrowotności społeczeństw, miała koncepcji „pola zdrowotnego” Lalonde'a zaprezentowana w A New Perspective on the Health of Canadians w 1974 roku. Teoretyczny model wieloczynnikowego uwarunkowania zdrowia, jaki stworzył autor, stał się przesłanką do podjęcia próby ustalenia hierarchii ważności poszczególnych czynników, przypisując im procentowo wyrażone znaczenie. Opatz (1985, s. 7) podaje, za Center for Disease Control (1975), następujący rozkład procentowego udziału czterech składowych elementów pola zdrowotnego w zgonach (Gniazdowski 1990, s. 85):

- styl życia - 53\%,

- środowisko (naturalne i społeczne) - $21 \%$,

- dziedziczenia, biologia człowieka - 16\%,

- opieka zdrowotna - 10\%.

Styl życia jako czynnik podlegający kontroli jednostki jest skategoryzowany jako najistotniejszy faktor warunkujący dobry stan zdrowia. Tak jak w przypadku wielorakich definicji stylu życia, rozpatrując jego związki ze zdrowiem, obserwuje się wiele sposobów definiowania prozdrowotnego stylu życia. Ostrowska (1999, s. 28) uważa, że prowadzenie prozdrowotnego stylu życia umożliwia osiągnięcie intencji nakierowanych na profil zdrowia, a wykluczenie zachowań zagrażających mu. Według Abla (1991) „na prozdrowotne style życia składają się nie tylko wzory zachowań związanych ze zdrowiem, ale także wartości i postawy reprezentowane przez ludzi w odpowiedzi na warunki ich społecznego, kulturowego i ekonomicznego środowiska" (Ostrowska 1999, s. 27). Zdrowy styl życia to także preferencja takich kanonów zachowań, znajdujących się wśród różnorodnych możliwości, poprzez które uzyskujemy i utrzymujemy dobre samopoczucie fizyczne, psychiczne i społeczne jednostki czy większej zbiorowości (Krawczyk 2002, s. 1-2).

Siciński w swoich pracach (1988) rozpatruje styl życia jako proces i efekt dokonywanych wyborów przez człowieka w ciągu całego życia. Jednym z istotnych składników zdrowego stylu życia (jeśli nie najważniejszym), jakie tworzą podstawę promocji zdrowia, jest regularna aktywność fizyczna (Drabik 1996, s. 215), pojęcie funkcjonujące w światowej literaturze przedmiotu jako „physical activity”. Definiuje się ją jako pracę mięśni szkieletowych wraz z całym zespołem towarzyszących jej zmian w organizmie (Kozłowski 1995), prowadzącą do ponadspoczynkowego wydatku energetycznego powodującego progresywne zmiany w stanie zdrowia (Drabik 1996, s. 215). Aktywność fizyczna jest podstawowym elementem podnoszenia poziomu sprawności fizycznej (Drabik 1996, s. 215). Osoba prowadząca 
zdrowy styl życia ze szczególnym uwzględnieniem zwiększonej aktywności fizycznej z dużym prawdopodobieństwem będzie cechowała się nie tylko zadowalającym stanem zdrowia, ale również lepszą sprawnością fizyczną. „Systematyczna aktywność fizyczna jest obowiązkiem człowieka w stosunku do własnego zdrowia" (Jegier 2005, s. 403).

Obecnie młodzi ludzie stają przed nowymi, dotychczas nieznanymi wyzwaniami, które zasadniczo powodują transformację w sferze ich świadomości i zachowań. W dobie wszechobecnych mediów czy informacji internetowej w życiu młodego człowieka spotyka się on z propozycjami nowych sposobów precyzowania hierarchizacji kanonów postępowania czy wyborów koncepcji przyszłych zamierzeń. Możemy z całą pewnością założyć, że młodzież akademicka, intelektualnie wybrana spośród własnego pokolenia rówieśników, wkraczająca w nową, nie tylko edukacyjną fazę życia, podchodząc świadomie i podmiotowo do swojego zdrowia oraz kierując się określonymi wartościami, czas wolny w dużym stopniu poświęca na jego pomnażanie. Jak pisał Danecki (1967): „o wyborze zachowań w czasie wolnym rozstrzyga jednostka zgodnie z przyjętą hierarchią wartości i potrzeb, respektowanymi obyczajami, całą rozległą gamą osobistych skłonności i upodobania". Czynnikiem decydującym o postępowaniu człowieka są więc wyznawane przez niego wartości, które nie tylko implikują styl życia, jego jakość, ale również wpływają na rozwój i kształtowanie drogi życiowej jednostki.

Dla młodego wieku typowe są próby odniesienia się do wartości wnoszonych przez starsze pokolenie, ich odrzucenie lub akceptacja stanowią przełom w życiu młodego człowieka związany z poszukiwaniem własnej tożsamości. Z tych względów problematyka wartości i postaw jest przedmiotem zainteresowań badawczych wielu dyscyplin nauki. Wieloznaczność określenia „wartość” spowodowała pojawienie się różnych jej definicji i prób klasyfikacji wartości. Szymański (1998, s. 31) wyróżnił 10 grup wartości: allocentryczne, prospołeczne, przyjemnościowe, związane z pracą, edukacyjne, związane z władzą, kulturalne, obywatelskie, rodzinne i materialne. Potocznie pojęcie „wartość” jest rozumiane jako coś szczególnie cennego, odpowiadającego wysokim wymaganiom. W definicjach socjologicznych podkreśla się standardy zachowań, przedmioty, wzorce i normy, do których dążą jednostka czy też grupa społeczna. Sygnalizuje to między innymi Szczepański (1970), określając wartości jako podmiot materialny lub idealny, ideę lub instytucję, przedmiot rzeczywisty lub wyimaginowany, w stosunku do których jednostka lub zbiorowość przyjmują postawę szacunku, równocześnie przypisując im ważną rolę w życiu.

Wartości jako czynnik stymulujący i regulujący zachowania i normy jednostek oraz grup społecznych umożliwiają zatem ich istnienie i aktywność jako całości. Każdy człowiek przywiązuje wagę do wielu wartości, angażując się w różnym stopniu w ich realizowanie. Jedna lub kilka wartości pełni funkcję czynnika fundamentalnego, predestynując i motywując działanie jednostki, a o różnicach decydują wewnętrzne treści tworzące układ tych wartości (Ostrowska 1994). System wartości człowieka i proces wartościowania mają ogromny wpływ na podstawowe aspekty funkcjonowania każdej jednostki. Okazuje się, że dla młodzieży akademickiej zdrowie i sportowa sylwetka oraz sprawność fizyczna są 
najważniejszymi wartościami ukierunkowanymi na ciało ludzkie, a dominującą motywacją w podejmowaniu aktywności fizycznej przez jednostkę jest przede wszystkim przyjemność i potrzeba ruchu oraz dbałość o własne zdrowie (Zdebska 2005).

\section{Cel pracy}

Krytycznie o zdrowiu i kulturze zdrowotnej studentów wypowiada się wielu badaczy. W licznych wartościowych raportach, zasobnych faktograficznie, nie znajdujemy pełnych wyjaśnień przyczyn zdrowotnego zaniechania. Mówimy nawet o paradoksie zaniechania działań prozdrowotnych osób wykształconych, zdrowotnie „oświeconych”, jak na przykład studentów medycyny. Warto tu wspomnieć wnioski, do jakich w 1987 roku doszła Rada Główna Nauki i Szkolnictwa Wyższego na podstawie materiałów Komisji Spraw Studenckich. W raporcie zatytułowanym: „Zdrowie i warunki socjalne młodzieży akademickiej” między innymi stwierdzono, że:

- stan zdrowia młodzieży akademickiej jest sygnałem alarmowym ukazującym pogorszenie wskaźników zachorowalności i chorobowości,

- konieczna jest poprawa zajęć obligatoryjnych i fakultatywnych wychowania fizycznego, rozwinięcie różnych form działalności sportowej i rekreacyjnej oraz

- niezbędne jest prowadzenie badań nad skutecznością realizowanych form wychowania fizycznego (Roman 1997, s. 89-98).

Wyniki poszukiwań w pracach empirycznych oraz wnioski płynące z powyższych twierdzeń dowodzą konieczności podjęcia działań propagujących i zachęcających młodzież akademicką do zwiększania ilości czasu wolnego spędzanego na aktywności fizycznej co najmniej w stopniu umiarkowanym. Chodzi zatem o to, aby czas wolny studentów zużytkowany był na zmianę złych zachowań w kierunku działań zwiększających dbałość o zdrowie. Związek dobrego zdrowia z jakością życia, efektywnością, skutecznością w pracy oraz z systemem preferowanych wartości został już na wiele sposobów dowiedziony. Zrozumiałe jest, że związek ten dla ludzi wykształconych i młodych winien być czytelny i bezdyskusyjny co nie znajduje niestety odbicia w praktyce profilaktycznej młodzieży akademickiej. Autorka pracy w trakcie działalności zawodowej ze studentkami Uniwersytetu Gdańskiego - uczestniczkami zajęć o przeznaczeniu zdrowotnym typu fitness - zauważyła zróżnicowanie ich postaw i zachowań: od zadowolenia z podejmowanego wysiłku fizycznego oraz afirmacji własnej cielesności po niechęć z udziału we wspólnym działaniu, manifestowaną odmową wzajemności. Dlatego też w badaniach podjęto próbę oceny prowadzonego stylu życia przez studentki UG, celem zaś jest wyjaśnienie związku między stylem życia studentek a ich przekonaniami zdrowotnymi i preferowanymi przez nie wartościami.

Zebrany materiał badawczy był próbą odpowiedzi na następujące pytania:

1. Jaki styl życia prowadzą studentki Uniwersytetu Gdańskiego? 
2. Czy istnieje związek pomiędzy stylem życia a przekonaniami zdrowotnymi studentek?

3. Czy istnieje związek pomiędzy stylem życia a preferowanymi przez studentki wartościami?

\section{Materiał i metoda}

Na wstępie autorka chce wyjaśnić, że przedstawione dane są wycinkiem większych badań przeprowadzonych w badaniach własnych, będących materiałem opracowanym w niepublikowanej rozprawie doktorskiej (Rogo 2010). Część dysertacji dotycząca stylu życia studentek była już prezentowana (Rogo 2014), w związku z tym w przedstawionym tutaj materiale badawczym ponownie zostały wykorzystane informacje dotyczące stylu życia studentek, ale w powiązaniu z innymi zmiennymi.

Badania zostały przeprowadzone na studentkach administracyjnie podzielonych na grupy dziekańskie studiów dziennych. Dobór próbki miał charakter losowy, a studentki przypisane były do jednego prowadzącego. Badania miały charakter anonimowej ankiety. Studentki uczęszczały na zajęcia regularnie, raz w tygodniu, od początku roku akademickiego 2006/2007 (1 X 2006). Objęto nimi studentki uczęszczające na obligatoryjne zajęcia typu fitness z I roku studiów i uczące się na różnych wydziałach: Zarządzanie, Ekonomia, Prawo i Administracja, Filologiczno-Historyczny, Nauki Społeczne oraz Biologia, Geografia i Oceanografia, z wyraźną przewagą studentek z wydziału Zarządzania - 43 osoby oraz Prawa i Administracji - 31 osób, a najmniejszą liczbą (6 osób) z Nauk Społecznych. Badaniem objęto 167 osób, lecz po odrzucenie niepełnych wyników badań studentek, które z różnych powodów nie uczestniczyły w części zajęć, ostatecznej analizie statystycznej poddano wyniki 150 osób w przedziale wiekowym 19-24 lata, z tym że najliczniejsza grupa znalazła się pomiędzy 19. a 20. rokiem życia (około $67 \%$ badanych - 101 osób).

W badania posłużono się schematem typu survey. Studentki odpowiadały na szereg pytań zawartych w kwestionariuszach ankiet (,Zachowanie a zdrowie”, „Międzynarodowy kwestionariusz aktywności fizycznej”, „Ankieta” oraz „Kwestionariusz ankiety"), dzięki którym zebrano informacje na temat prowadzonego przez badane stylu życia, a zawarte w nich pytania pogrupowano i wyodrębniono styl życia jako całość oraz jego wskaźniki z uwzględnieniem najważniejszego wskaźnika tej zmiennej - aktywności fizycznej. Intensywność i częstość podejmowania aktywności fizycznej uznano za wyraz prozdrowotnego usposobienia studentek. Odpowiedziom na pytania ankietowe zostały przypisane punkty. W zakresie każdego wskaźnika punkty przydzielone wszystkim pytaniom ankietowym odzwierciedlały zasadę: niższe natężenie elementu prozdrowotnego wyraża niższą liczbę punktów. Każdą ze zmiennych ustandaryzowano (przydzielona liczba punktów za odpowiedź na pytanie ankietowe w ramach danej składowej prozdrowotności), a następnie zsumowano ocenę punktową w skali 0-100 (0 - najniższa, 100 - najwyższa), stosując 
transformację według skali T. W dalszej kolejności przeprowadzono analizę skupień (grupowanie metodą k-średnich), uwzględniając zmienne (wskaźniki stylu życia i styl życia jako wynik łączny), tak by otrzymane 2 grupy studentek (PLUS i MINUS) jak najbardziej różniły się między sobą. Grupa PLUS to studentki o ocenie stylu życia powyżej średniej dla wszystkich badanych, a grupa MINUS to studentki o ocenie stylu życia poniżej średniej dla wszystkich badanych.

W dalszej części badań jakościowych do pomiaru zmiennych zastosowano:

1. Skalę Wartości Schelerowskich - służy ona do oceny subiektywnej ważności wartości oraz ich podobieństwa do obiektywnego, idealnego prototypu; została skonstruowana przez Piotra Brzozowskiego (1995). Inspiracją dla autora była teoria obiektywnej hierarchii wartości niemieckiego filozofa Maxa Schelera, który żył na przełomie XIX i XX wieku. Scheler, tworząc narzędzie, wyszedł z założenia, że istnieją trzy różne rodzaje bytów: psychiczne, idealne i materialne. Uważał, że obiektywnie istnieją zarówno wartości, jak i hierarchie. Hierarchie zaś, obowiązujące w danej epoce historycznej czy grupie społecznej, są tylko wariantami hierarchii uniwersalnej. Najlepszą psychometrycznie wersją wartości jest wersja SWS D-50, którą zastosowałam w pracy do pomiaru ważności poszczególnych wartości. Zaletą tej skali jest możliwość pomiaru na skali interwałowej, to, że nie stwarza artefaktów związanych z rangowaniem według zasady ,jedna wartość - jedna ranga" (więcej wartości może otrzymać tę samą liczbę punktów) oraz nie jest ipsatywna (ocena dowolnej wartości nie zależy od ocen innych wartości). Skala Wartości Schelerowskich składa się z pięćdziesięciu wartości. Tworzą one (a właściwie ich nazwy) sześć skal podstawowych. Są to skale wartości: Hedonistyczne $(H)$, Witalne (W), Estetyczne (E), Prawdy (P), Moralne (M) oraz Święte (Ś). Dodatkowo wyniki analiz statystycznych pozwoliły na wyodrębnienie czterech podskal czynnikowych, z których dwie - Sprawności i Siły Fizycznej (SSF) oraz Wytrzymałości (Wyt.) - wchodzą w skład podskali wartości Witalnych, a dwie - Świętości Świeckie (ŚŚ) i Świętości Religijne (ŚR) - wchodzą w skład podskali wartości Świętych. Do poszczególnych podskal wartości zaliczono następujące pozycje:

wartości Hedonistyczne - 8 pozycji: dostatnie życie, miłość erotyczna, posiadanie przyjemności, radość życia, wygoda, wypoczęcie, życie pełne wrażeń; wartości Witalne - 6 pozycji:

1. Siła i Sprawność Fizyczna - 3 pozycje: siła fizyczna, sprawność, sprężystość ciała;

2. Wytrzymałość - 3 pozycje: odporność na zmęczenie, umiejętność znoszenia chłodu i umiejętność znoszenia głodu;

wartości Estetyczne - 7 pozycji: elegancja, gustowność, harmonia, ład rzeczy, proporcjonalność kształtów, regularność rysów, uporządkowanie;

wartości Prawdy - 8 pozycji: inteligencja, logiczność, mądrość, obiektywność, otwarty umysł, rozumienie, szerokie horyzonty myślowe, wiedza;

wartości Moralne - 11 pozycji: dobroć, honor, miłość bliźniego, pokój, pomaganie innym, prawdomówność, rzetelność, szczerość, uczciwość, uprzejmość, życzliwość;

wartości Święte 10 pozycji:

- Świeckie - naród, kraj, niepodległość, ojczyzna, państwo, patriotyzm;

- Święte - Bóg, wiara, zbawienie, życie wieczne. 
W kwestionariuszu poszczególne wartości uporządkowano alfabetycznie. Do zadań badanego należy ocena poszczególnych wartości, z użyciem 101-punktowej skali (od 0 do 100 punktów) stosownie do ich ważności. Czasu badania nie ograniczono, przeciętnie wynosił on 15-20 minut.

2. Skalę BM/HF (przekonania biomedyczne/holistyczno-funkcjonalne). Skonstruowana przez zespół Zakładu Zdrowia i Psychologii Klinicznej UAM Poznań - zawiera 20 twierdzeń dotyczących różnych aspektów życia. Określa w 6-stopniowej skali (od 0 do 5), w jakim stopniu każde z twierdzeń dotyczących różnych aspektów zdrowia wyraża osobiste przekonania badanego. Następnie zaznaczone twierdzenia zostały przydzielone do wymiaru HF (10 twierdzeń) i do wymiaru BM (10 twierdzeń). W danym wymiarze zostały zebrane i zsumowane punkty odpowiadające określonej liczbie na skali (minimalnie 0 punktu, maksymalnie 50 punktów), wskazując prezentowane przekonania zdrowotne badanego.

Do obliczeń charakterystyk liczbowych poszczególnych zmiennych przedstawionych w pracy za pomocą powszechnie stosowanych parametrów wykorzystano pakiet statystyczny firmy Statsoft STATISTICA wersja 8.

W badaniach zastosowano następujące metody statystyczne:

- statystyki podstawowe,

- test Shapiro-Wilka dla weryfikacji hipotez o normalności rozkładów,

- analizę wariancji ANOVA oraz jej nieparametryczne odpowiedniki: testy Kruskal-Wallisa i Manna-Whitneya,

- analizę korelacji i regresji,

- analizę skupień metodą k-średnich.

\section{Wyniki}

\section{STYL ŻYCIA STUDENTEK}

W pierwszej kolejności sporządzono profil stylu życia studentek. Wyodrębniono 2 grupy/skupienia studentek, do których przynależały uczestniczki zajęć. Grupa nazwana PLUS grupuje studentki o ocenie ich stylu życia i jego składowych powyżej średniej dla wszystkich badanych (poza zmienną styl życia - dostateczna ilość snu), natomiast grupa nazwana MINUS to studentki o ocenie stylu życia poniżej średniej dla wszystkich badanych.

Tabela 1. Średnie stylu życia i jego składowych dla skupień prowadzonego stylu życia uczestniczek zajęć mierzone odchyleniem standardowym od średniej wyników wszystkich badanych

\begin{tabular}{|l|c|c|c|}
\hline \multicolumn{1}{|c|}{ Składowe stylu życia } & $\begin{array}{c}\text { PLUS } \\
(\mathbf{n}=\mathbf{6 4})\end{array}$ & $\begin{array}{c}\text { MINUS } \\
(\mathbf{n}=\mathbf{8 6})\end{array}$ & $\begin{array}{c}\text { Istotność } \\
\text { różnic }\end{array}$ \\
\hline Jakość posiłków & 0,63 & $-0,47$ & $0,0000^{*}$ \\
\hline Regularność posiłków & 0,04 & $-0,03$ & 0,6717 \\
\hline Kontrola masy ciała & 0,23 & $-0,17$ & $0,0130^{*}$ \\
\hline
\end{tabular}


Tabela 1 (cd.)

\begin{tabular}{|l|c|c|c|}
\hline \multicolumn{1}{|c|}{ Składowe stylu życia } & $\begin{array}{c}\text { PLUS } \\
\text { (n= 64) }\end{array}$ & $\begin{array}{c}\text { MINUS } \\
\text { (n= 86) }\end{array}$ & $\begin{array}{c}\text { Istotność } \\
\text { różnic }\end{array}$ \\
\hline Aktywność fizyczna & 0,57 & $-0,43$ & $0,0000^{*}$ \\
\hline Unikanie używek i lekarstw & 0,01 & $-0,01$ & 0,8845 \\
\hline Zachowania profilaktyczne & 0,35 & $-0,26$ & $0,0001^{*}$ \\
\hline Radzenie sobie ze stresem & 0,52 & $-0,38$ & $0,0000^{*}$ \\
\hline Czystość ciała i otoczenia & 0,14 & $-0,10$ & 0,1487 \\
\hline Dostateczna ilość snu & $-0,16$ & 0,12 & 0,0992 \\
\hline Właściwe stosunki międzyludzkie & 0,53 & $-0,40$ & $0,0000^{*}$ \\
\hline Styl życia - wynik łączny & 0,72 & $-0,54$ & $0,0000^{*}$ \\
\hline Liczba studentek w skupieniu & 64 & 86 & \\
\hline
\end{tabular}

( Wartości różne istotnie statystycznie przy $p<0,05)$

Obserwując styl życia prowadzony przez wszystkie badane studentki UG, stwierdzamy, że aż 57\% z nich prowadzi niezdrowy styl życia. Z analizy statystycznej wynika, że studentki zaliczone do grupy PLUS osiągały istotnie wyższe średnie wartości niż studentki grupy MINUS aż w sześciu spośród dziesięciu wskaźników stylu życia oraz w stylu życia jako wynik łączny. Świadczy to o ważności tych składowych w prowadzonym stylu życia przez badane osoby oraz o jego jakości. Największe zróżnicowanie pomiędzy skupieniami prowadzonego stylu życia widoczne jest na poziomie czterech zmiennych: jakości posiłków, aktywności fizycznej, w radzeniu sobie ze stresem i we właściwych stosunkach międzyludzkich oraz w stylu życia jako wyniku łącznym na korzyść studentek grupy PLUS.

\section{Przekonania zdrowotne studentek w grupach prowadzonego stylu życia}

W grupach prowadzonego stylu życia przeprowadzono badanie przekrojowe poziomu przekonań zdrowotnych dla zmiennej: „przekonania biomedyczne”, metodą parametryczną. Dla zmiennej „przekonania holistyczno-funkcjonalne” ze względu na odrzucenie hipotezy o normalności rozkładów w grupach badanie przeprowadzono metodą nieparametryczną H Kruskala-Wallisa.

Tabela 2. Wartość średnich i odchylenia standardowego wewnętrznego poczucia kontroli i przekonań biomedycznych studentek w kategoriach prowadzonego stylu życia

\begin{tabular}{|c|c|c|c|c|c|c|}
\hline Przekonania zdrowotne BM/HF & \multicolumn{3}{|c|}{ MINUS (n= 86) } & \multicolumn{3}{c|}{ PLUS (n = 64) } \\
\hline Przekonania biomedyczne & 25,8 & \pm & 4,27 & 25,1 & \pm & 4,58 \\
\hline
\end{tabular}


Ze względu na odrzucenie hipotezy o normalności rozkładów w grupach poniżej przedstawiono wartości mediany i odchylenia ćwiartkowego (jako miar wartości przeciętnej i rozproszenia dla rozkładów istotnie różnych od normalnego) dla zmiennej „przekonania holistyczno-funkcjonalne”.

Tabela 3. Wartości mediany i odchylenia ćwiartkowego dla przekonań holistyczno-funkcjonalnych studentek według przynależności do skupień prowadzonego stylu życia

\begin{tabular}{|c|c|c|c|c|c|c|}
\hline Przekonania zdrowotne BM/HF & \multicolumn{3}{|c|}{ MINUS (n = 86) } & \multicolumn{3}{c|}{ PLUS (n = 64) } \\
\hline Przekonania holistyczno-funkcjonalne & 33,5 & \pm & 2,5 & 34,0 & \pm & 2,25 \\
\hline
\end{tabular}

Tabela 4. Wartości funkcji testującej i prawdopodobieństwa testowego w badaniu istotności różnic poczucia podmiotowości i przekonań zdrowotnych studentek w kategoriach przynależności do skupień prowadzonego stylu życia

\begin{tabular}{|l|c|c|}
\hline \multicolumn{1}{|c|}{ Przekonania zdrowotne BM/HF } & $\begin{array}{c}\text { Wartość funkcji } \\
\text { F lub H }\end{array}$ & $\begin{array}{c}\text { Wartość prawdopodobieństwa } \\
\text { testowego } \mathbf{p}\end{array}$ \\
\hline BM-HF przekonania biomedyczne & 0,87 & 0,3534 \\
\hline $\begin{array}{l}\text { BM-HF przekonania } \\
\text { holistyczno-funkcjonalne }\end{array}$ & $-0,80$ & 0,4246 \\
\hline
\end{tabular}

Przeprowadzone badanie przekrojowe przekonań zdrowotnych u studentek według prowadzonego stylu życia wskazały na brak istotnego związku pomiędzy obiema grupami.

Wyższy średni poziom przekonań biomedycznych występuje u studentek ze skupienia MINUS niż u studentek skupienia PLUS. Mimo iż różnica ta nie jest istotna statystycznie można wnioskować, że w badanej grupie studentki skupienia MINUS kierują się przekonaniem, że w zachowaniu i pomnażaniu własnego zdrowia nie należy ufać działaniom prozdrowotnym jednostki na jego rzecz, lecz skłaniają się ku innym działaniom. Takie przekonanie studentek tego skupienia znajduje wyraz w prowadzonym przez nie stylu życia.

Wartość przeciętna poziomu przekonań holistyczno-funkcjonalnych przybiera wyższe wartości u studentek ze skupienia PLUS, lecz różnica ta nie jest statystycznie istotna. Prezentując wyniki uzyskane za pomocą Skali PZ Heleny Sęk i współpracowników, można wnioskować, że studentki należące do skupienia o prozdrowotnym stylu życia cechują się przywiązaniem do holistycznego nurtu odnoszącego się do przekonań zdrowotnych. Jako osoby zwracające uwagę na wiele elementów prowadzonego przez siebie stylu życia, z aktywnością fizyczną na czele, z poczuciem przekonania o możliwości osiągnięcia obranego przez siebie celu, okazują się osobami skłaniającymi się w kierunku przekonania powiązania działań własnych na rzecz pomnażania zdrowia. Traktując je jako wyraz wzajemnej relacji pomiędzy strukturami funkcjonalnymi człowieka oraz pomiędzy człowiekiem a jego środowiskiem, aktywnie uczestniczą w procesie utrzymania i promowania zdrowia, gdyż traktują je wielowymiarowo, również świadomie. 


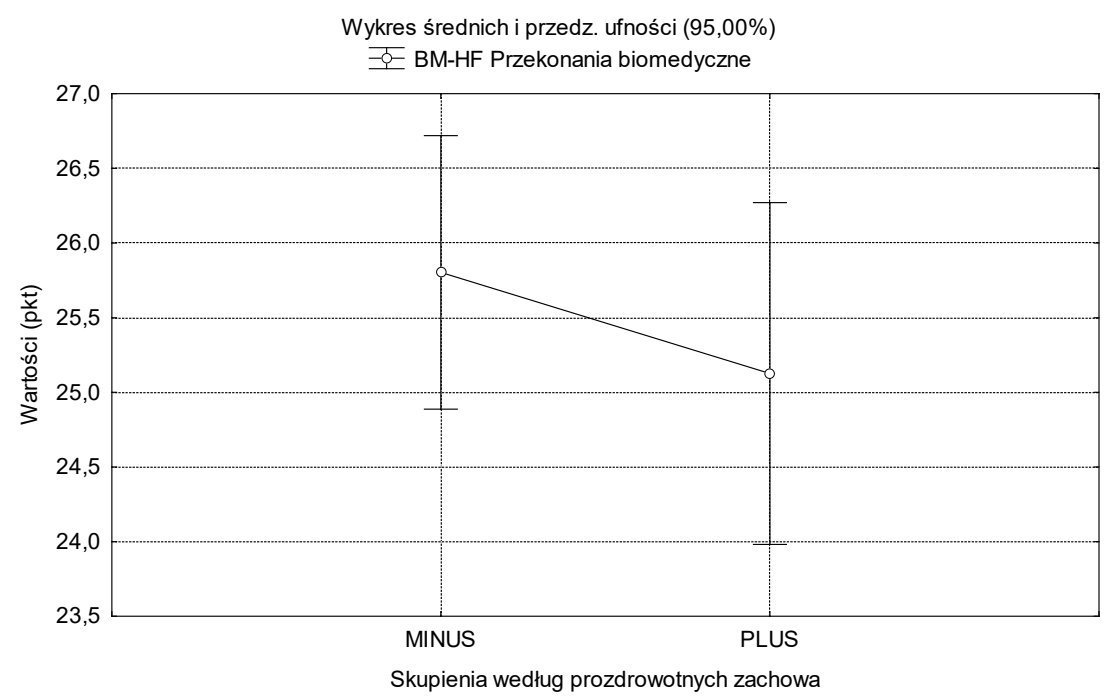

Wykres 1. Średnie wartości poziomu przekonań biomedycznych dla grup studentek ze skupień prowadzonego stylu życia

Wykr. ramka-wąsy względem grup

Zmienna: BM-HF Przekonania holistyczno-funkcjonalne

$\square$ Mediana $\square$ 25\%-75\% I Min-Maks

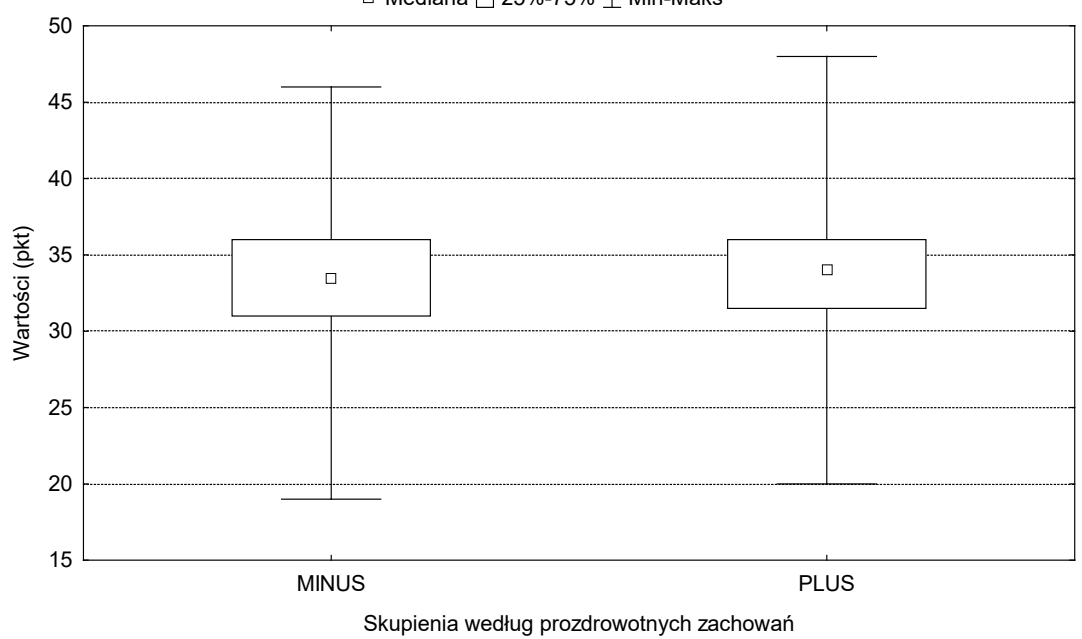

Wykres 2. Przeciętne wartości przekonań holistyczno-funkcjonalnych dla grup studentek dla skupień według prowadzonego stylu życia

Znajduje to także odzwierciedlenie w zachowaniach zdrowotnych badanych kobiet. 


\section{PREFERENCJE WARTOŚCI STUDENTEK}

Jednym z najbardziej aktualnych tematów naszych czasów jest hierarchia wartości współczesnego człowieka, wyznaczająca jego postawę wobec rzeczy i ludzi, a co za tym idzie - korespondująca również z obranym stylem życia. System tych wartości wiąże się nie tylko z pochodzeniem człowieka, ale przede wszystkim z rozwojem, aspiracjami czy wyznaczonymi przez każdego z nas celami. Rodzaj wartości najbardziej dla jednostki znaczący i sposób ich realizacji świadczy o dojrzałości osoby, jej zdrowiu psychicznym czy sile motywacji.

W badaniach własnych do pomiaru tej zmiennej użyto Skali Wartości Schelerowskich, służącej - według autora - ocenie subiektywnej ważności wartości dla osoby badanej, która umożliwia zaznajomienie się z preferencjami, które są dla niej najistotniejsze. Scheler nadaje wartościom charakter hierarchiczny i tylko realizacja wartości niższego rzędu może prowadzić do osiągania wartości zlokalizowanych wyżej w strukturze aksjologicznej.

Dokonano podstawowych analiz statystycznych w badanej grupie studentek, aby określić preferowane przez nie wartości. Wykonane analizy przedstawia poniższa tabela.

Tabela 5. Podstawowe statystyki dla zmiennych składowych testu SWS ogółu badanych studentek

\begin{tabular}{|l|r|r|r|r|r|c|}
\hline \multicolumn{1}{|c|}{ Składowe SWS } & X & SD & Mini. & Max. & $\begin{array}{c}\text { Kwartyl } \\
\text { dolny }\end{array}$ & $\begin{array}{c}\text { Kwartyl } \\
\text { górny }\end{array}$ \\
\hline SWS wartości moralne & 80,74 & 9,75 & 50,00 & 99,55 & 75,00 & 87,27 \\
\hline SWS wartości prawdy & 77,40 & 11,83 & 37,50 & 100,00 & 70,00 & 85,63 \\
\hline SWS wartości hedonistyczne & 72,84 & 12,94 & 35,00 & 96,25 & 65,00 & 81,88 \\
\hline SWS świętości religijne & 68,62 & 28,61 & 0,00 & 100,00 & 47,50 & 92,50 \\
\hline SWS sprawności i siły fizycznej & 64,94 & 19,59 & 10,00 & 100,00 & 53,33 & 78,33 \\
\hline SWS wartości święte & 60,93 & 19,54 & 4,00 & 99,00 & 48,50 & 74,00 \\
\hline SWS wartości witalne & 59,12 & 18,02 & 8,33 & 96,67 & 48,33 & 73,33 \\
\hline SWS wartości estetyczne & 56,18 & 16,91 & 9,29 & 97,14 & 44,29 & 68,57 \\
\hline SWS świętości świeckich & 55,80 & 22,23 & 6,67 & 98,33 & 40,00 & 71,67 \\
\hline SWS wartości wytrzymałości & 53,30 & 21,81 & 6,67 & 100,00 & 36,67 & 70,00 \\
\hline
\end{tabular}

Studentki UG najbardziej cenią sobie wartości moralne i prawdy, co przy obecnej tendencji obniżającego się morale społeczeństwa może napawać optymizmem. Niepokoić może fakt, że najmniej cenią sobie wartości witalne, powiązane ze zdrowiem i odpornością organizmu na odczuwane niedogodności. 
Poniżej znajduje się graficzna prezentacja uzyskanych wyników.

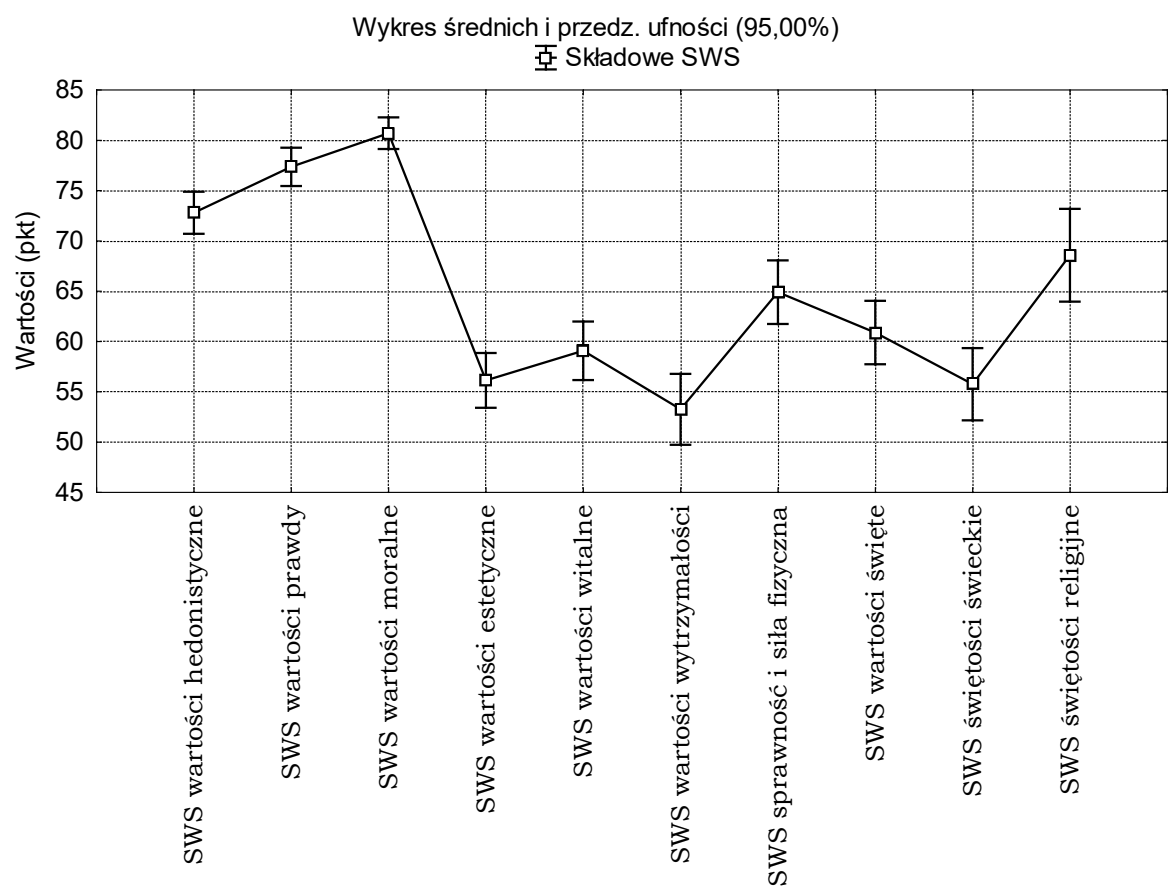

Wykres 3. Średnie wartości i przedziały ufności dla zmiennych testu SWS dla całej grupy

\section{Preferencje wartości studentek a ich styl życia}

Przeprowadzono analizę wartości wyznawanych przez studentki przynależące do poszczególnych skupień prozdrowotnego stylu życia. Badanie przekrojowe różnic w wartościach SWS dla skupień PLUS i MINUS zrealizowano parametryczną metodą analizy wariancji ANOVA.

Z uwagi jednak na niespełnienie założenia o normalności rozkładów w grupach dla siedmiu zmiennych SWS: wartości hedonistyczne, wartości prawdy, wartości estetyczne, sprawność i siła fizyczna, wartości święte, świętości świeckie oraz świętości religijne, zaszła konieczność przeprowadzenia dodatkowo testu nieparametrycznego (Manna-Whitneya). 
Tabela 6. Wartości średnich i odchylenia standardowego oraz funkcji testującej F i prawdopodobieństwa testowego (p) dla składowych testu SWS według przynależności do skupień prowadzonego stylu życia

\begin{tabular}{|l|c|c|c|c|c|c|c|c|}
\hline \multicolumn{1}{|c|}{$\begin{array}{c}\text { Zmienne składowe } \\
\text { testu SWS }\end{array}$} & \multicolumn{3}{|c|}{ MINUS (n= 86) } & \multicolumn{3}{c|}{ PLUS (n= 64) } & F & p \\
\hline SWS wartości moralne & 79,43 & \pm & 9,49 & 82,5 & \pm & 9,89 & 3,69 & 0,0566 \\
\hline SWS wartości witalne & 56,07 & \pm & 17,6 & 63,23 & \pm & 17,87 & 5,99 & $0,0156^{*}$ \\
\hline $\begin{array}{l}\text { SWS wartości } \\
\text { wytrzymałości }\end{array}$ & 51,4 & \pm & 21,2 & 55,86 & \pm & 22,52 & 1,54 & 0,2162 \\
\hline
\end{tabular}

( Wartości różne istotnie statystycznie przy $p<0,05)$.

Analiza wykazała obecność istotnej różnicy w przyjmowanych wartościach zmiennej „SWS wartości witalne” pomiędzy skupieniem PLUS i MINUS. Studentki o wyższej prozdrowotności prowadzonego stylu życia charakteryzowały się istotnie wyższą preferencją wartości witalnych. Studentki ze skupienia PLUS prowadzące prozdrowotny styl życia cenią sobie najbardziej wartości witalne. Cechują się więc dbałością o utrzymanie swojej sprawności fizycznej na zadowalającym je poziomie, utrzymanie ładnej, sprężystej sylwetki.

Ze względu na odrzucenie hipotezy o normalności rozkładów w grupach przedstawiono poniżej wartości mediany i odchylenia ćwiartkowego (jako miar wartości przeciętnej i rozproszenia dla rozkładów istotnie różnych od normalnego) dla pozostałych zmiennych.

Tabela 7. Wartości mediany i odchylenia ćwiartkowego oraz wartości funkcji testującej

Z Manna-Whitneya i prawdopodobieństwa testowego $(p)$ dla składowych testu SWS według przynależności studentek do skupień prowadzonego stylu życia

\begin{tabular}{|l|c|c|c|c|c|c|c|c|}
\hline \multicolumn{1}{|c|}{$\begin{array}{c}\text { Zmienne składowe } \\
\text { testu SWS }\end{array}$} & \multicolumn{3}{|c|}{ MINUS (n=86) } & \multicolumn{3}{c|}{ PLUS (n= 64) } & Z & p \\
\hline SWS wartości hedonistyczne & 73,1 & \pm & 8,75 & 73,7 & \pm & 8,75 & $-1,68$ & 0,0930 \\
\hline SWS wartości prawdy & 77,8 & \pm & 8,13 & 79,3 & \pm & 8,44 & $-1,28$ & 0,1995 \\
\hline SWS wartości estetyczne & 57,8 & \pm & 10,3 & 61,7 & \pm & 13,0 & $-0,84$ & 0,3988 \\
\hline $\begin{array}{l}\text { SWS sprawność } \\
\text { i siła fizyczna }\end{array}$ & 65,8 & \pm & 14,1 & 71,6 & \pm & 10,0 & $-3,16$ & $0,0016^{*}$ \\
\hline SWS wartości święte & 61,2 & \pm & 12,0 & 68,5 & \pm & 15,5 & $-1,27$ & 0,2050 \\
\hline SWS świętości świeckie & 58,3 & \pm & 16,6 & 60,0 & \pm & 17,2 & $-0,78$ & 0,4381 \\
\hline SWS świętości religijne & 75,0 & \pm & 22,5 & 80,6 & \pm & 21,8 & $-1,52$ & 0,1295 \\
\hline
\end{tabular}

( ${ }^{*}$ Wartości różne istotnie statystycznie przy $p<0,05$ ).

Analiza wykazała istnienie statystycznie istotnej różnicy w przyjmowanych wartościach zmiennej „SWS sprawność i siła fizyczna” pomiędzy skupieniem PLUS i MINUS, co obrazuje poniższy wykres. 


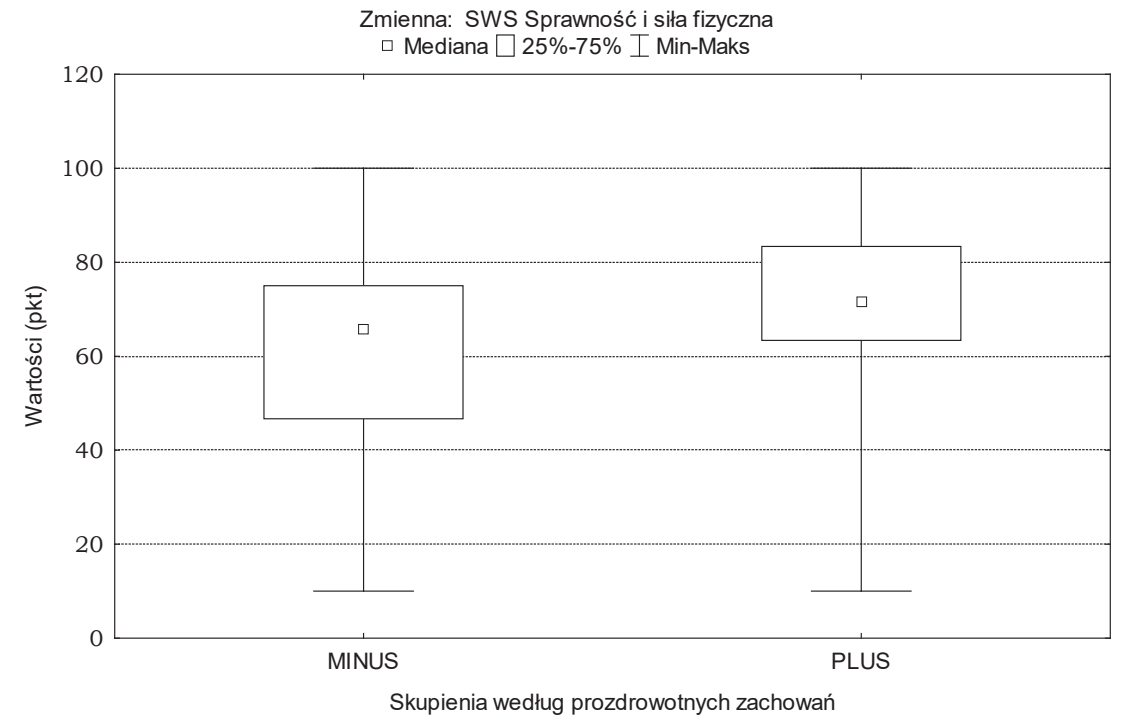

Wykres 4. Przeciętne wartości sprawności i siły fizycznej dla ustanowionych skupień prowadzonego stylu życia

Istotnie wyższe przeciętne wartości sprawności i siły fizycznej występują u studentek ze skupienia PLUS. Przeciętny środkowy wynik przekroczył wartość 71 pkt, podczas gdy w skupieniu MINUS było to niecałe 66 pkt. Należy zwrócić również uwagę na większe skupienie wyników wokół mediany dla skupienia PLUS. Bardzo interesujące wydaje się zjawisko występowania w obu skupieniach identycznych wartości skrajnych zarówno maksymalnych, jak i minimalnych badanej zmiennej.

\section{Podsumowanie}

[N]ad zdrowiem trzeba pracować i praca ta ma charakter pedagogiczny. Chodzi bowiem o wykształcenie trwałych nawyków higieniczno-kulturalnych, odpowiednich postaw wobec zdrowia fizycznego i psychicznego, wreszcie o pewne kwantum wiedzy i umiejętności.

Maciej Demel

Przegląd piśmiennictwa jednoznacznie wskazuje na ciągłą zmianę stylu życia studentów. Częstość realizacji działań rekreacyjno-zdrowotnych, zmieniająca się także moda na różne formy spędzania czasu wolnego, z pewnością powinny mieć znaczący wpływ na poziom zdrowia młodzieży akademickiej (Demel 1980; Drozdowski 1980). Raporty donosiły o kryzysie zdrowia środowiska studentów, objawiającym się wzmożonym nikotynizmem, nieracjonalnym odżywianiem, komputerowym uzależnieniem i sprawnościowym zaniedbaniem. Badania Patoka 
i współpracowników (1997), Deckerta (1999, s. 10-11), Makuły (1999), Biernat (2001, s. 7-11) czy Gacek (2002, s. 26-27) dowiodły, że młodzież akademicka w ograniczonym zakresie podejmuje aktywność fizyczną poza zajęciami obligatoryjnymi. Wyniki badań Jankowskiego wskazują, że około 25\% przebadanej młodzieży w wieku 17-21 lat podkreśla zależność między aktywnością fizyczną a zdrowiem, natomiast około $70 \%$ takiej zależności nie widzi. Według autora jest to jedna z przyczyn braku popularyzacji wśród młodzieży zachowań prozdrowotnych z aktywnością fizyczną na czele (Jankowski 1994, s. 99-111).

Interesujące wnioski płyną z badań Roman, w których aż $90 \%$ badanych studentów z pięciu ośrodków akademickich Poznania zadeklarowało posiadanie utrwalonych nawyków związanych z ochroną własnego zdrowia (nawyki higieniczne, dietetyczne czy usprawniające ciało). Kształtowanie tych nawyków, według młodzieży, miało miejsce w okresie poprzedzającym studia. Tylko $37 \%$ z nich uznało, że dbałość o własne zdrowie tkwi w prowadzonym stylu życia oraz w dostępności do opieki zdrowotnej. Wartość zdrowia wskazywana była przez badanych studentów na wysokim poziomie jej akceptacji, a $77 \%$ badanych stwierdziło, że kształtowanie nawyków zdrowotnych winno być zadaniem szeroko pojętego systemu edukacyjnego (Roman 1998). W 2002 roku przeprowadzono badania East-West Health Gap, z których wynika, że wśród krajów objętych badaniami (Finlandia, Hiszpania, Niemcy, Polska, Rosja) Polska pod względem liczby osób dorosłych systematycznie podejmujących aktywność fizyczną zajmowała ostatnie miejsce (Rutkowska 2004, s. 175-180). Z kolei wyniki badań z 2004 roku przeprowadzonych w Polsce na reprezentatywnych grupach wiekowych społeczeństwa w wieku 15 lat i więcej wskazują, że aktywność fizyczną w czasie wolnym o umiarkowanej intensywności uprawia 31,3\% kobiet (Woynarowska 2008, s. 56). W badaniach Malary (2006, s. 132-134) zauważono, że studenci w wielu przypadkach wykazują się wiedzą na temat zasad prawidłowego odżywiania się, zgubnego skutku stosowania używek i zdrowotnego wpływu uprawiania sportu, lecz mimo to praktyczne jej zastosowanie jest niewielkie.

W 2008 roku przeprowadzono badania wśród studentów Wielkiej Brytanii w celu odnalezienia czynników ryzyka zagrażających zdrowiu młodzieży akademickiej. Wyniki wykazały, że występują trzy takie czynniki ryzyka związane z prowadzonym stylem życia: $70 \%$ badanych wykazało się brakiem uczestniczenia w aktywności fizycznej, $66 \%$ spożywało zbyt małą od zalecanej dzienną porcję owoców i warzyw, a u 56\% odnotowano upijanie się co najmniej raz w tygodniu. Dodatkowo stwierdzono, że kobiety doświadczają w trakcie studiowania większego stresu psychicznego niż mężczyźni (Dodd 2010). Dlatego należałoby wziąć pod uwagę w programach edukacyjnych młodzieży również wnioski, do jakich doszli autorzy badań przeprowadzonych wśród studentów Uniwersytetu w Walencji: zwiększenie aktywności fizycznej jest bardzo cenne dla zdrowia publicznego, gdyż nie tylko pomaga w redukcji tkanki tłuszczowej, ale poprawia też samopoczucie psychiczne i wizerunek jednostki (Castillo 2010).

Wyniki badań własnych nad prowadzonym stylem życia studentek UG w badanej grupie potwierdzają powyższe konstatacje. Stwierdzamy, że $57 \%$ z nich prowadzi niezdrowy styl życia, co może być sygnałem niepokojącym. Zmienne 
najbardziej różnicujące badane to styl życia jako całość jest oraz dwie jego składowe: jakość posiłków i aktywność fizyczna.

Uzyskane wyniki potwierdzają wcześniejsze spostrzeżenia, że dla studentek skupienia PLUS o prozdrowotnym stylu życia w takim właśnie zachowaniu istotne jest kierowanie się chęcią uzyskania i utrzymania sprawności fizycznej jako wyrazu zdrowia, gdyż wartości z nim powiązane (wartości witalne oraz „SWS sprawność i siła fizyczna") cenią sobie one najwyżej. Podobny optymizm wypływa między innymi z socjopedagogicznej diagnozy funkcjonowania wartości zdrowia w świadomości młodzieży studiującej w Poznańskim Ośrodku Akademickim. Okazuje się, że zgromadzony materiał faktograficzny wskazuje na bardzo wysoki stopień akceptacji tej wartości, ale tylko $45 \%$ młodzieży uważa, że studenci sami odpowiadają za swoje zdrowie. Według badanych jednym z najważniejszych czynników zagrażających zdrowiu jest niekorzystny dla organizmu styl życia oraz jego składowa uznana za najważniejszą - sposób odżywiania się jednostki (Modrzejewski 1998, s. 127-142).

Wyniki kolejnych analiz badań własnych ilustrują, że w świadomości studentek odnotować można obecność obu nurtów postrzegania zdrowia: przekonania biomedyczne i przekonania holistyczno-funkcjonalne. Istotne jest, że w stopniu nieznacznie większym studentki skupienia PLUS identyfikują się z holistycznym paradygmatem stylu życia, zgodnie z którym uprawianie aktywności fizycznej daje wymierne, pozytywne efekty na różnych płaszczyznach, w tym społecznej i psychicznej (Kuński 2003, s. 15-25). Rezultaty te dowodzą ścisłego związku prozdrowotnego stylu życia studentek nie tylko z preferowanymi wartościami powiązanymi ze zdrowiem, ale również z holistycznym nurtem odnoszącym się do przekonań zdrowotnych. Studentki zwracające uwagę na wiele aspektów prowadzonego przez siebie stylu życia, z aktywnością fizyczną na czele, okazują się osobami skłaniającymi się w kierunku przekonania o roli powiązania psychiki i ciała na rzecz pomnażania zdrowia. Postrzegając je jako wyraz wzajemnej relacji pomiędzy strukturami funkcjonalnymi człowieka oraz pomiędzy człowiekiem a jego środowiskiem, aktywnie uczestniczą w procesie utrzymania i promowania zdrowia, gdyż traktują je wielowymiarowo, również świadomie. Znajduje to odzwierciedlenie w zachowaniach zdrowotnych badanych kobiet.

\section{Wnioski}

Uzyskane wyniki i ich analiza pozwoliły sformułować następujące wnioski:

1. Obserwując styl życia prowadzony przez wszystkie badane studentki UG, stwierdzamy, że większość z nich prowadzi niezdrowy styl życia. Studentki prowadzące prozdrowotny styl życia osiągały istotnie wyższe średnie wartości aż w sześciu spośród dziesięciu wskaźników stylu życia oraz w stylu życia jako wynik łączny niż studentki o antyzdrowotnym stylu życia. Zmiennymi najbardziej różnicującymi badane był styl życia oraz jego składowe: jakość posiłków i aktywność fizyczna. 
2. Studentki o prozdrowotnym stylu życia prezentują nieznacznie wyższe powiązanie $z$ holistycznymi przekonaniami zdrowotnymi w porównaniu z tymi, które takiego stylu nie preferują.

3. Studentki prowadzące prozdrowotny styl życia kierują się w nim wartościami powiązanymi ze zdrowiem, jakimi są: wartości witalne oraz sprawność i siła fizyczna.

\section{Literatura}

Biernat E., Prozdrowotny styl życia studentów szkoły głównej Handlowej, „Kultura Fizyczna” 2001, nr 1-2, s. 7-11.

Brzozowski P., Skala Wartości Schelerowskich - SWS. Podręcznik, Pracownia Testów Psychologicznych PTP, Warszawa 1995.

Castillo I., Molina-García J., Adiposity and psychological well-being: effects of physical activity on university students in Valencia, Spain, „Rev Panam Salud Publica” 2009, 26(4), Oct., s. 334-340, http://www.ncbi.nlm.nih.gov/pubmed/?term=Adiposity+and+psychological+well-being\%3A+ effects+of+physical+activity+on+university+students+in+Valencia\%2C+Spain (dostęp: 10.05.14).

Danecki J., Czas wolny. Mity i potrzeby, Warszawa 1967.

Deckert A., Kultura fizyczna studentów Akademii Medycznej im. Karola Marcinkowskiego w Poznaniu, „Kultura Fizyczna” 1999, 3-4, s. 10-11.

Demel M., Pedagogika zdrowia, Wydawnictwo WSiP, Warszawa 1980.

Dodd L.J., Al-Nakeeb Y., Nevill A., Forshaw M.J., Lifestyle risk factors of students: A cluster analytical approach, http://www.ncbi.nlm.nih.gov/pubmed/?term=Forshaw+MJ.\%2C+Lifestyle+risk+factor s+of+students\%3A+A+cluster+analytical+approach (dostęp: 14.05.2010).

Drabik J., Aktywność fizyczna w treningu zdrowotnym osób dorosłych. Część II, Gdańsk 1996, s. 215.

Drozdowski S., Rytm wybranych cech sprawności fizycznej w czasie czteroletnich studiów wychowania fizycznego, Akademia Wychowania Fizycznego w Poznaniu, Poznań 1980.

Gacek M., Motywy i poziom aktywności ruchowej wśród studentów I roku AWF w Krakowie, „Kultura Fizyczna" 2002, 11-12, s. 26-27.

Gniazdowski A., Zachowania zdrowotne. Podstawowe zależności, [w:] A. Gniazdowski (red.), Zachowania zdrowotne, zagadnienia teoretyczne, próba charakterystyki zachowań zdrowotnych społeczeństwa polskiego, Wydawnictwo Instytut Medycyny Pracy, Łódź 1990, s. 85.

Jankowski K., Zdrowy styl życia. Promocja zdrowia, „Nauki Społeczne i Medycyna” 1994, nr 1-2, s. 99-111.

Jegier A., Aktywność ruchowa w promocji zdrowia oraz zapobieganiu i leczeniu chorób przewlekłych, [w:] A. Jegier, K. Nazar, A. Dziak (red.), Medycyna sportowa, Polskie Towarzystwo Medycyny Sportowej, Warszawa 2005, s. 403.

Kozłowski St., Nazar K., Wprowadzenie do fizjologii klinicznej, PZWL, Warszawa 1995.

Krawczyk Z., Aktywność fizyczna a zdrowy styl życia w perspektywie integracji europejskiej, „Kultura Fizyczna" 2002, s. 1-2.

Kuński H., Trening zdrowotny osób dorosłych, stosowany w praktyce, „Medycyna Sportiva” 2003, 7, Supl. 1, s. 15-25.

Makuła W., Postawy prosomatyczne młodzieży akademickiej Krakowa, „Kultura Fizyczna” 1999, nr 3-4.

Malara B., Góra-Kupilas K., Jośko J., Odżywianie się i inne elementy stylu życia studentów Politechniki Śląskiej - doniesienie wstępne, „Zdrowie Publiczne” 2006, 116(1), s. 132-134.

Modrzejewski J., Roman E., Studenci Poznańskiego Ośrodka Akademickiego wobec wartości zdrowia i jego zagrożeń, „Pedagogika Szkoły Wyższej” 1998, nr 11/12, s. 127-142.

Opatz J.P., A Promer of Heath promotion. Creating healthy Organization Cultures, Oryn Publication, Inc., Washington, D.C. 1985, s. 7. 
Ostrowska A., Prozdrowotne style życia, [w:] A. Ostrowska, Styl życia a zdrowie, FiS PAN, Warszawa 1999, s. 28.

Ostrowska K., W poszukiwaniu wartości, Gdańsk 1994.

Patok J., Jasiński M., Ożarowski P., Drabik J., Szymański P., Aktywność fizyczna studentów I roku UG, „Kultura Fizyczna” 1997, nr 7-8.

Pilicz St. (red.), Rozwój sprawności i wydolności fizycznej dzieci i młodzieży: raport z badań, Wydawnictwo AWF, Warszawa 1988.

Roman E., Sytuacja zdrowotna młodzieży studiującej, „Pedagogika Szkoły Wyższej” 1997, nr 8, s. 89-98.

Roman E., Młodzież studiująca wobec wartości własnego zdrowia, ERUDITUS s.c. Poznań 1998.

Rogo B., Styl życia studentek a ich postawa na zajęciach fitness i motywy uczestnictwa, „Journal of Health Sciences" 2014, 13, s. 356-368.

Rogo B., Styl życia i sprawność fizyczna studentek a ich poczucie koherencji, rozprawa doktorska, AWFiS, Kraków 2010.

Rutkowska E., Aktywność fizyczna w medycynie holistycznej, „Wychowanie Fizyczne i Sport” 2004, t. 48 , s. $175-180$.

Siciński A. (red.), Style życia w miastach polskich (u progu kryzysu), Wrocław 1988.

Szczepański J., Elementarne pojęcia socjologii, Państwowe Wydawnictwo Naukowe, Warszawa 1970.

Szymański M.J., Wartości nauczycieli i uczniów szkół zawodowych, [w:] S. Kwiatkowski (red.), Nowe uwarunkowania edukacji szkolnej, Instytut Badań Edukacyjnych, Warszawa 1998, s. 31.

Woynarowska B., Edukacja zdrowotna. Podręcznik akademicki, PWN, Warszawa 2008, s. 56.

Zdebska H., Olszewski T., Kultura fizyczna a wartości ciała i zdrowia, Annales Universitatis Mariae Curie-Skłodowska, Lublin - Polonia, vol. Ix, suppl. xvi, 660 sectio d, 2005. 